\title{
Peningkatan Kualitas Pembelajaran Explanation Text Menggunakan Model Problem Based Learning Berbasis Lesson Study
}

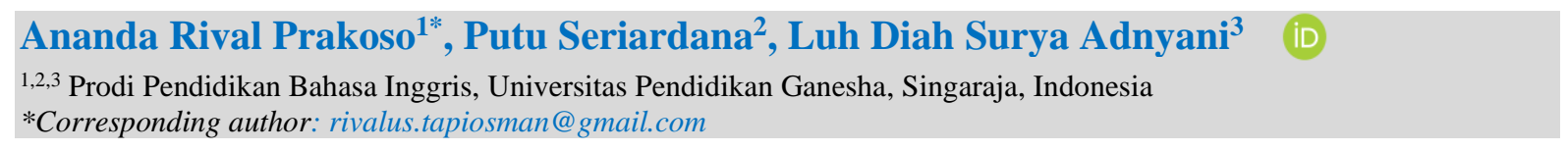

\begin{abstract}
Abstrak
Permaslahaan siswa dalam menulis teks eksplanasi mulai dari memahami struktur-struktur dari teks eksplanasi, menentukan topik, membuat tema sehingga menjadi sebuah kerangka karangan, sampai pada pengembangan kerangka karangan yang arahnya tertuju pada pembuatan teks. Selain itu, minat siswa dalam menulis juga masih rendah. Tujuan penelitian ini untuk menganalisis model problem based learning terhadap kualitas pembelajaran explanation text pada mata pelajaran Bahasa Inggris siswa SMA. Penelitian ini merupakan penelitian kualitatif. Penelitian ini menggunakan model problem based learning berbasis lesson study. Terdapat tiga tahap yang dilaksanakan dalam kegiatan lesson study, yaitu: perencanaan (plan), pelaksanaan (do), dan refleksi (see). Subjek yang dipilih adalah peserta didik kelas 11 di SMA. Hasil penelitian menunjukkan bahwa pemberian model teks kepada peserta didik, pembedahan teks, sampai merangkum teks bisa diikuti peserta didik dengan lancar namun, waktu 15 menit untuk menanggapi meresapi isi video yang disajikan dirasakan masih kurang. Partisipasi siswa secara umum sudah baik selama kegiatan pembelajaran, dan keterampilan yang dilatihkan juga berhasil terlihat dari hasil worksheet. Berdasarkan hasil penelitian, dapat disimpulkan bahwa Model pembelajaran problem based learning berbasis lesson study dirasa efektif dalam mengajarkan explanation text siswa SMA.
\end{abstract}

Kata kunci: Keterampilan Menulis, Lesson Study, Problem Based Learning

\section{Abstract}

Students' problems in writing explanatory texts start from understanding the structures of explanatory texts, determining topics, making themes so that they become an essay outline, to developing an essay outline that is directed at making texts. In addition, students' interest in writing is still low. The purpose of this study was to analyze the problem-based learning model on the quality of explanation text learning in English subjects for high school students. This research is qualitative. This study uses a problem-based learning model based on lesson study. There are three stages carried out in lesson study activities, namely: planning (plan), implementation (do), and reflection (see). The subjects selected were 11th-grade students in high school. The results showed that giving the text model to students, dissecting the text, and summarizing the text could be followed by students smoothly, however, 15 minutes to respond to the content of the video presented was felt to be lacking. In general, student participation was good during the learning activities, and the skills that were trained were also successfully seen from the worksheet results. Based on the results of the study, it can be concluded that the problembased learning model based on lesson study is considered effective in teaching explanation text in high school students.

Keywords: Writing, Lesson Study, Problem Based Learning

\section{INTRODUCTION}

Bahasa Inggris adalah salah satu mata pelajaran yang dibelajarkan di Sekolah Menegah Atas (Kurniasih et al., 2019; Simbolon, 2014). Pelaksanaan pembelajaran di dalam kelas merupakan salah satu tugas utama guru yang dapat diartikan sebagai kegiatan yang ditujukan untuk membelajarkan siswa. Dalam proses pem- belajaran masih sering ditemui adanya kecenderungan siswa lebih pasif sehingga mereka lebih banyak menunggu sajian guru daripada mencari dan menemukan sendiri pengetahuan, keterampilan atau sikap yang mereka butuhkan. Pembelajaran bahasa Inggris harus mencakup 4 keterampilan berbahasa, yaitu: membaca (reading), menyimak (listening), berbicara (speaking), dan menulis (writing) secara terpadu (Marhaeni, 2012; Sahraini \& Madya, 2015; Susilo, 2016). Semua aspek tersebut memiliki keterkaitan seperti hubungan menulis dengan membaca yang sangat erat, apabila

$\begin{array}{lll}\text { History: } & & \text { Publisher: Undiksha Press } \\ \text { Received } & \text { : July 15, } 2020 & \text { Licensed: This work is licensed under } \\ \text { Revised } & \text { : February 13, } 2021 & \text { a Creative Commons Attribution 3.0 License } \\ \text { Accepted } & \text { : April 26, 2021 } & \text { CC ( ) (? } \\ \text { Published } & \text { : May 1, 2021 }\end{array}$


kita menuliskan sesuatu maka prinsipnya kita ingin agar tulisan tersebut dibaca oleh orang lain, paling sedikit dapat dibaca oleh diri sendiri.

Menulis adalah suatu aktivitas kompleks. Kompleksitas menulis tertelak pada tuntutan kemampuan mengharmonisasikan berbagai aspek, seperti pengetahuan tentang topik yang dituliskan, kebiasaan menata isi tulisan secara runtut dan mudah dicerna, wawasan dan keterampilan mengolah unsur-unsur bahasa sehingga tulisan menjadi enak dibaca, serta kesanggupan menyajikan tulisan yang sesuai dengan konvensi atau kaidah penulisan (Hizati et al., 2018; Pangaribuan, 2020). Tulisan dapat dikatakan baik jika memenuhi syarat diantaranya ialah (1) kemampuan untuk menemukan masalah yang akan ditulis, (2) kepekaan terhadap kondisi pembaca, (3) kemampuan menyusun rencana penulisan, (4) kemampuan menggunakan bahasa, (5) kemampuan memulai tulisan, serta (6) kemampuan memeriksa tulisan. Untuk dapat menulis seperti itu, maka seorang calon penulis diantaranya memerlukan kemauan dan kemampuan. Dengan menulis, seorang individu juga bisa mengembangkan kecerdasan, menulis mengembangkan daya inisiatif dan kreativitas, menulis menumbuhkan kepercayaan diri dan keberanian, dan dapat mendorong kebiasaan serta memupuk kemampuan dalam menemukan, mengumpulkan, dan mengorganisasikan informasi (Muslainy, 2017; Rohman, 2018).

Berdasarkan hasil observasi dan wawancara yang dilakukan, diketahui bahwa terdapat beberapa permasalahannya yang dihadapi siswa dalam menulis teks eksplanasi mulai dari memahami struktur-struktur dari teks eksplanasi, menentukan topik, membuat tema sehingga menjadi sebuah kerangka karangan, sampai pada pengembangan kerangka karangan yang arahnya tertuju pada pembuatan teks eksplanasi sesuai dengan strukturnya yaitu, pernyataan umum, deretan penjelas, dan interpretasi. Namun, kendala lain dari segi praktiknya, minat siswa terhadap menulis teks eksplanasi tergolong rendah. Hal tersebut disebabkan guru hanya memberikan teori tentang teks eksplanasi dan struktur teks hanya dalam bentuk lisan saja dan tidak memberikan contoh yang konkret kepada siswa agar dapat meningkatkan minat mereka untuk menulis teks eksplanasi. Selain itu, pembelajaran guru yang monoton juga membuat siswa merasa tidak tertarik dalam megikuti proses pembelajaran.

Permasalahan tersebut jika dibiarkan akan berdampak buruk terhadap proses pembelajaran. Maka diperlukan solusi untuk mengatasi permasalahan tersebut, salah satu solusi yang dapat dilakukan ialah dengan menerapkan model pembelajaran Problem Based Learning. Model problem based learning adalah adalah model yang mengajarkan peserta didik untuk menyusun pengetahuannya sendiri, dapat mengembangkan ketrampilan lebih tinggi dan inquiry, dan mampu meningkatkan rasa percaya diri. Selain itu, model problem based learning menuntut peserta didik untuk berkolaborasi dengan peserta didik lainnya guna memecahkan suatu permasalahan, yang dapat mengembangkan kemampuan berpikir kritis peserta didik. Pada penerapannya, model problem based learning akan dipadukan dengan lesson study untuk memaksimalkan proses pembelajaran.

Lesson study merupakan pendekatan komprehensif untuk pembelajaran yang profesional dilaksanakan secara tim melalui tahapan-tahapan perencanaan, implementasi pembelajaran di dalam kelas dan observasi, refleksi, dan diskusi data hasil observasi serta pengembangan pembelajaran lebih lanjut (Dewi et al., 2018; Harta et al., 2019; Susanto, 2016). Lesson study memberikan banyak kesempatan bagi guru untuk berkolaborasi dengan sesama sejawat bidang ilmu, sehingga kreatifitas dalam proses pembelajaran dapat merubah prespektif dosen tentang pembelajaran serta untuk belajar melihat proses mengajar yang dilakukan dosen dari prespektif mahasiswa. Lesson Study dilaksanakan melalui tiga tahapan, yaitu plan (perencanaan), do (pelaksanaan), dan see (refleksi) (Karlina et al., 2017; Widiasari \& Sumantri, 2020; Yulianto et al., 2017). Belum banyak penelitian yang mendalam mengenai penerapan model problem based learning berbasis lesson study untuk meningkatkan kualitas pembelajaran explanation text pada mata pelajaran Bahasa Inggris. 
Beberapa penelitian yang relevan dengan penelitian ini seperti penelitian yang dilakukan oleh (Hizati et al., 2018) yang menemukan bahwa model problem based learning berbantuan media gambar berseri berpengaruh positif terhadap keterampilan menulis teks eksplanasi siswa kelas VIII SMP. Kemudian penelitian yang dilakukan oleh (Pangaribuan, 2020) menemukan bahwa terjadi peningkatan keterampilan mengidentifikasi struktur dan unsur bahasa teks eksplanasi siswa kelas VIII SMP dengan pembelajaran problem based learning. Kemudian penelitian lain juga dilakukan dan menemukan bahwa pembelajaran menulis teks eksplanasi dengan menggunakan model problem based learning yang berbasis audiovisual telah terbukti dapat menarik minat, motivasi, dan produktivitas siswa dalam menghasilkan karya tulis (Fitriah et al., 2019). Tujuan penelitian ini untuk menganalisis model problem based learning terhadap kualitas pembelajaran explanation text pada mata pelajaran Bahasa Inggris siswa SMA kelas XI.

\section{MATERIALS AND METHODS}

Penelitian ini merupakan penelitian kualitatif. Penelitian ini menggunakan model problem based learning berbasis lesson study. Terdapat tiga tahap yang dilaksanakan dalam kegiatan lesson study, yaitu: perencanaan (plan), pelaksanaan (do), dan refleksi (see). Subjek yang dipilih adalah peserta didik kelas 11 di SMA Laboratorium Undiksha Singaraja pada semester genap tahun ajaran 2018/2019. Lesson study ini dilaksanakan dalam satu tim yang terdiri dari guru model dan observer (dosen pembimbing, guru pamong, rekan sejawat). Observasi dilaksakan secara langsung pengamat dan secara tidak langsung oleh guru model. Guru model mengobservasi dari sudut pandang guru, sedangkan pengamat mengobservasi dari sudut pandang siswa. Pengamat tidak diperkenankan untuk terlibat langsung maupun melakukan rinteraksi dalam proses pembelajaran di dalam kelas. Pengamat hanya melihat dan mengobservasi dengan menggunakan lembar observasi. Dalam lembar observasi, pengamat menuliskan temuan, menulis catatan penting, menulis nomor siswa yang melakukan interaksi dan sebagainya. Data yang dibutuhkan dalam lesson study ini antara lain RPP, media, serta worksheet, dokumentasi dalam bentuk foto dan video apabila memungkinkan. Foto dan video diambil menggunakan telepon genggam. RPP, worksheet, dan media dikumpulkan dari setiap tahapan. Implementasi kegiatan lesson study di kelas didokumentasikan dalam bentuk foto dan video. Didapatkan juga data-data mengenai kejadian-kejadian penting dikelas dalam bentuk lembar observasi. Selain itu, data seperti jurnal guru dan jurnal kelas diambil sebagai data tambahan pendukung.

\section{RESULTS AND DISCUSSION}

\section{Hasil Penelitian}

Pada tahap perencanaan (plan) dilakukan pada Jumat, 8 Maret 2019. Peneliti yang dalam hal ini juga bertindak sebagai guru model, berdiskusi dengan guru pamong mengenai kelas yang akan digunakan untuk pelaksanaan lesson study. Tidak hanya berdiskusi mengenai pemlihan kelas, namun juga topik materi yang akan digunakan dikelas. Setelah berdiskusi, diperolehlah keputusan untuk menggunakan kelas XI MIPA 2, dengan alasan karena kelas ini akan beranjak ke materi baru. Topik materi yang dipilih adalah Explanation text. Selanjutnya, penulis beserta anggota kelompok merancang RPP yang akan digunakan sebagai panduan mengajar dikelas. Selain RPP, para anggota kelompok juga berdiskusi mengeni strategi yang tepat untuk digunakan dalam mengajarkan tentang topik yang telah dipilih. Sebagai tambahan, RPP juga dilengkapi media yang tepat yang telah didskusikan agar materi yang ingin disampaikan bisa sampai kepada peseta didik dengan baik. Media yang digunakan adalah power point dan video untuk memberikan informasi tambahan peserta 
didik tentang explanation text. Selanjutnya penulis juga mempersiapkan worksheet untuk penugasan siswa dikelas.

Kegiatan lesson study berjalan dengan lancar di kelas XI MIPA2. Hal pertama yang dilakukan guru adalah membagikan nomor punggung kepada peserta didik sesuai dengan nomor absen mereka. Setelah itu dilanjutkan dengan memberikan briefing singkat mengenai kegiatan leson studyyang akan dilakukan dikelas. Pada saat bel pergantian berbunyi, guru memulai kelas dengan mengucapkan salam kepada peserta didik dalam bahasa Inggris, dilanjutkan dengan memeriksa kehadiran siswa. Guru mereview materi pada pertemuan sebelumnya dengan meminta peserta didik menyebutkan isi materi di pertemuan sebelumnya. Kemudian guru model menyampaikan tujuan pembelajran untuk pertemuan ini.Selain tujuan pembelajaran, terlihat juga peserta didik diberikan sedikit motivasi tentang manfaat setelah mempelajari materi ini.Kegiatan pembuka diakhiri dengan sebuah game Chinese whisperer tentng fenomena alam. Pemenang dari game ini diberikan apresiasi oleh guru dan siswa dengan tepuk tangan yang meriah. Dimana didalam game ini peserta didik mulai diarahkan tentang topik yang akan diberikan melalui kegiatan permainan berkelompok. Kegiatan pembuka berlangsung sekitar 15 menit mulai dari awal menyapa sampai akhir permainan.

Kegiatan inti dimulai dengan guru membuka slide power point berisi foto tentang fenomena alam. Peserta didik diminta untuk menyebutkan nama gejala alam yang diketahui. Selain itu peserta didik juga diminta menyebutkan hal-hal yang dirasakan ketika mengalami sesuai di gambar yang ditunjuk. Tidak hanya itu, siswa juga diberikan kesempatan untuk menjelaskan singkat sesuai pengetahuan mereka mengenai hal yang terjadi di gambar yang ditampilkan. Kemudian, siswa diberikan suatu masalah untuk dipecahkan secara berkelompok. Sebelum masuk kegiatan diskusi, siswa terlebih dahulu diberikan guided questions $5 \mathrm{~W}+1 \mathrm{H}$ untuk membantu mereka memecahkan masalah tersebut.

Masuk ke kegitan diskusi kelompok yang pertama, siswa diberikan dua teks eksplanasi untuk dibedakan struktur teks satu sama lain. Tidak hanya isi struktur teks, tetapi siswa juga mencari unsur-unsur Bahasa yangterdapat dalam teks bersama-sama. Kemudian setelah tugas selesai dikerjakan sesuai batas waktuyang diberikan, siswa diberikan kesempatan untuk mempresentasikan jawabannya didepan kelas melalui perwakilan kelompok. Disini jawaaban siswa akan dikoreksi bersama-sama. Guru terlihat membenarkan jawaban siswa yang diperdebatkan satu sama lain. Setelah jawaban diluruskan oleh gurunya, siswa menjawab mengerti dengaan penjelasan guru.

Kegiatan inti dilanjutkan dengan guru memutarkan video tentang dua gejala alam yaitu tsunami and volcano eruption. Setelah memutarkan video, guru mengajukan pertanyaan $5 \mathrm{~W}+1 \mathrm{H}$ terkait dengan isi video. Siswa yang mau menjawab dengan benar akan mendapatkan nilai plus di aspek keaktifan siswa. Dilanjutkan dengan guru meminta siswa menuliskan jawabannya di papan tulis. Lalu guru beserta siswa mendiskusikan jawabanjawaban tersebut. Kegiatan selanjutnya adalah membuat rangkuman berdasarkan video yang telah ditonton. Siswa dibentuk kelompok-kelompok yang terdri dari 4-5 orang. Didalam kelompok siswa akan membuat rangkuman video yang nantinya akan dipresentasikan kedepan kelas. Sebelum dipresentasikan, siswa diberikan juga kesempatan untuk berkonsultasi dengan guru mengenai rangkuman yang telah dibuat. Setelah batas waktu yang diberikan habis, siswa diminta utuk mempresentasikan hasil tugas kedepan kelas. Urutan maju ditentukan dengan cara undian perwakilan kelompok. Selama presentasi kelompok, kelompok lain diminta menyimak dan mengajukan satu pertanyaan kepada kelompok yang maju. Guru memberikan penilaian speaking kepada kelompok yang sedang presentasi. Kegiatan inti diakhiri dengan diambil kesimpulan Bersama dari hasil presentasi para kelompok.

Kegiatan terakhir adalah kegiatan penutup yang dimulai dengan guru merefleksi pembelajaran yang telah dilakukan bersama siswa. Kemudian, guru menanyakan hal-hal yang 
sudah dipelajarai dan masih ada kesulitan kepada siswa. Kegiatan penutup ditutup dengan penarikan kesimpulan oleh guru dan peserta didik serta pemberian informasi tentang kegiatan dan materi yang akan ada pada pertemuan selanjutnya oleh guru. Kemudian, guru mengucapkan salam penutup pembelajaran diikuti oleh siswa.

Tahap see atau refleksi pembelajaran dilakukan setelah tahap do selesai dilakukan, yaitu pada Selasa, 20 Maret 2019 di ruang perpustakaan SMA LAB. Adapun hasil dari refleksi kegiatan lesson study yaitu sebagai berikut.

Pertama, kontrak keterampilan yang dilatihkan. Keterampilan yang akan diajarkan adalah keterampilan menulis. Tahapan-tahapan pembelajaran menulis dikelas sudah dirasakan berjalan dengan baik. Hal ini bisa dilihat dari mulai pemberian model teks kepada peserta didik, pembedahan teks, sampai merangkum teks bisa diikuti peserta didik dengan lancar. Namun, waktu 15 menit untuk menanggapi meresapi isi video yang disajikan dirasakan masih kurang.

Kedua, kesesuaian pelaksanaan pembelajaran dengan RPP. Secara umum, kegiatan yang berlangsung di dalam kelas sudah sesuai dengan RPP. Dari kegiatan pembuka, inti, sampai penutup sudah sesuai dengan rencana. Materi yang disajikan sudah sesuai dengan karakteristik peserta didik. Hal ini ditambah dengan pemilihan media berupa gambar dan video bisa untuk mempermudah peserta didik memahami materi peserta didik sehingga pembelajaran berlangsung secara maksimal dan efektif. Penyisipan game di kegiatan pembuka juga menambah semangat siswa untuk menerima materi yangakan diajarkan. Dibalik kesesuaian kegiatan dengan RPP yang direncanakan, time management dari guru dirasa belum maksimal. Ada beberapa kelompok yang meminta tambahan waktu untuk mempresentasikan hasil kerja keompok mereka. Hal ini diakibatkan oleh kurangnya atensi siswa terhadap waktu dalam menyelesaikan tugas yang diberikan.

Ketiga, partisipasi siswa dalam pembelajaran. Partisipasi siswa secara umum sudah baik selama kegiatan pembelajaran. Dimulai dari kegiatan pembuka yang melibatkan siswa untuk mereview pembelajaran sebelumnya, dan dalam pelaksanaan permainan sebagian besar siswa menunjukkan rasa antusiasme yang tinggi untuk berpartisipasi. Siswa dirasa cukupaktif untuk menjawab pertanyaan dari guru meski ada yang harus ditunjuk dahulu. Selain itu, siswa juga terlihat aktif untuk berkolaborasi didalam kelompok mereka.

Keempat, keberhasilan keterampilan yang dilatihkan. Keterampilan yang dilatihkan berhasil untuk dicapai. Dapat dilihat dari hasil worksheet dan quiz mereka yang hampir semua siswa sudah menjawab dan jawabannya secara umum benar. Siswa juga sudah cukup baik dalam mengembangkan teks dengan antusias walaupun kemampuan dan waktu mereka terbatas. Di fase mengomunikasi, siswa mampu mempresentasikan teks bersama kelompoknya dengan baik. Selain itu peserta didik di akhir kegiatan mampu menyimpulkan keterampilan apa yang telah dipelajari pada pertemuan kali ini.

Kelima, simpulan dari pelaksanaan pembelajaran. Bisa diambil kesimpulan dari pelaksaan pembelajaran yang telah dilakukan bahwa meskipun kegiatan yang dilaksanakan sudah sesuai dengan rencana yang tertuang di RPP, masih diperlukan perbaikan manajemen waktu sehingga dalam pelaksanaan kegiatan bisa berlangsung sangat efektif. Selain itu, guru sudah cukup baik dalam mengapresiasi hasil belajar sswa, juga penambahan kegiatan permainan yang bertujuan untuk menarik minatsiswa. Namun, proses pembelajaran masih terkesan monoton yang lebih banyak pengerjaan worksheet secara berkelompok. Kelemahankelemahan yang masih diamati. Dalam lesson study yang telah dilaksanakan, tentu masih ada kelemahan yang terlihat dikelas walaupun sudah mempersiapkan kegiatan dengan matang. Adapun kelemahan - kelemahan yang masih dapat diamati, yaitu 1) time management. Dalam kegiatan menjawab worksheet secara berkelompok peserta didik masih kesulitan menjawab walaupun sudah dibimbing oleh guru. Hal ini menyebabkan peserta didik membutuhkan waktu lebih dari yang ditentukan untuk menyelesaikan tugasnya. Hal ini berdampak pada 
kegiatan selanjutnya yaitu mempresentasikan hasil kerja, dimana tidak semua kelompok mendapat giliran untuk menpresentasikan hasil kerjanya pada hari itu.kesimpulannya, satu kegiatan bisa menghabiskan waktu lebih dari yang ditentukan; 2) media: power point yang ditampilkan dirasa kurang maksimal karena tulisan terlalu berdempetan sehingga siswa dibelakang maju ke barisan depan karena kesulitan membaca. Sebagai tambahan, posisi device proyektor yang ada dikelas kurang pas sehingga ada bagian power point tidak tampak di kertas layar. Hal ini bisa disiasati oleh guru dengan memprint out teks yang ada di powerpoint yang kemudian dibagikan kepada siswa; 3) bahasa: penggunaan bahasa Inggris masih didalam kisaran $80 \%$. Dimana hal ini bertujuan untuk membiasakan siswa dengan bahasa Inggris. Kasus ini bisa dimaklumi karena kemampuan siswa dalam berbahasa Inggris dirasakan masih kurang sehingga guru menyesuaikan level berbahasa Inggris dengan siswa. Disisi lain, guru sudah baik dalam menerapkan instruksi-instruksi sehari-hari menggunakan Bahasa inggris untuk membiasakan mereka.

\section{Pembahasan}

Pada tahapan pengenalan masalah, peserta didik terlihat kurang responsif. Ini terlihat dari kurangnya tanggapan peserta didik ketika diberi pertanyaan pancingan mengenai tanggapan tentang gambar yang ditunjukkan. Namun, usaha guru dengan membuat pertanyaan panduan didalam slide power point membuat peserta didik bisa mengungkapkan satu per-satu tanggapan mereka. Penggunaan strategi bertanya $5 \mathrm{~W}+1 \mathrm{H}$ dapat mempermudah peserta didik untuk mengaktualisasikan pikirannya daripada hanya sekedar diminta membayangkan (Pranata, 2013; Ratnayanti et al., 2016). Kemudian pada tahap pengumpulan data, peserta didik diminta untuk menemukan informasi penting yang ada dalam dua teks model. Ini dimaksudkan untuk nantinya peserta didik mampu menggali informasi tambahan dalam rangka berpikir kritis untuk membantu memecahkan masalah. RPP yang dimaksudkan untuk membuat peserta didik berpikir kritis sudah cukup baik, namun peserta didik masih belum mampu untuk menggali informasi lebih lanjut dalam tahap ini. Ini terlihat dari jawaban peserta didik yang cenderung banyak tersurat daripada memasukkan informasi tersirat yang terdapat dalam text.

Tahap selajutnya merupakan berbagi inofrmasi. Pada tahap ini peserta didik diminta untuk menonton video yang berisi explanation text tentang fenomena alam. Didalam kegiatan ini, peserta didik diminta untuk mencatat informasi-informasi penting untuk kemudian dijabarkan menjadi text tulis. Peserta didik kemudian menonton dengan seksama sambal mencatat infrmasi-informasi penting yang bisa digunakan untuk membuat text sekaligus menjawab rumusan masalah yang dijabarkan di awal. Dengan waktu yang diberikan oleh guru, peserta didik meminta untuk dua kali pemutaran video. Dengan menekankan informasi yang harus dicatat peserta didik, guru kemudian memutar video sekali lagi dengan harapan bisa memberikan peserta didik kesempatan untuk mengonfirmasi data yang telah mereka catat sebelumnya. Kurangnya waktu pemahaman video yang terjadi saat pelaksanaan bias terjadi karena peserta didik tidak bisa langsung serta merta memahami isi video dengan kelompoknya. Kemepetan waktu juga jadi alasan mengapa waktu untuk memahami video menjadi singkat. Hal ini juga diyakini oleh kolaborator sebagai salah satu kendala dalam pembelajaran karena media seharusnya mempermudah peserta didik untuk memahami materi. Guru bisa mensiasati hal ini dengan menyederhanakan video yang ditampilkan dengan mengurang informasi-informasi yang tidak perludidalam video. Sehingga hal ini akan bisa dilaksanakan pada tahap perencanaan media ajar.

Secara umum, tahapan pembelajaran yang dilaksanakan pada saat pelaksanaan lesson study sudah sesuai yang direncanakan. Kolaborasi antara guru pelaku lesson study dengan guru mata pelajaran dan dosen universitas membuat rancangannya menjadi seefektif mungkin. Namun dibalik, bagusnya RPP tetap terjadi kendala-kendala dalam waktu 
pelaksanaan. Seperticontohnya, management waktu dari guru yang terlihat masih kurang. Ini terlihat dari molornya kegiatan pada waktu pembedahan text untuk menggali informasi sebagai bahan pemecahan masalah. Seblumnya diperkirakan peserta didik akan mudah melaksanakan kegiatan tersebut karena guru sudah menyusun lembar kerja disertai penanda untuk mempermudah peserta didik menemukan informasi yang dicari. Pada kenyataanya, waktu kegiatan menjadi molor dikarenakan peserta didik banyak yang belum aktif bekerja sama dengan kelompoknya sehingga proses mengerjakan soal menjadi lebih lambat. Meskipun guru sudah berusaha mengingatkan peserta didik untuk bekerja membagi tugas dengan para anggota kelompok, peserta didik masihbelum bisa mengeksekusi soal yang diterima.

Meskipun rencana pelaksanaan pembelajaran telah dirancang dengan baik, kemungkinan terjadinya kendala pada waktu pelaksanaan tetap bisa terjadi. Seperti contohnya, molornya waktu pengerjaan tugas dalam diskusi kelompok. Serta dalam, pemutaran media video yang bertujuan untuk mempermudah peserta didik memahami materi ternyata masih belum efektif. Ini bisa terjadi, karena pada saat tahapan "Plan" penyusunan RPP didasarkan pada asumsi bahwa peserta didik akan mengikuti pembelajaran dengan baik. Dengan catatan guru harus menyesuaikan dengan kemampuan peserta didik. Setelah penyesuaian dirasa cukup, maka RPP dapat dilaksanakan. Mengingat keapikan rencana pembelajaran, guru memiliki ekspektasi terhadap keberhasilan pembelajaran. Namun, yang terjadi berada diluar pemikiran guru waktu pengerjaan menjadi molor. Hal ini membuktikan bahwa adaptasi-adaptasi melalui lesson study harus selalu dilakukan. Adaptasi yang dimaksud adalah, guru harus terus merefleksi pembelajaran-pembelajaran yang sudah delaksanakan. Ini bertujuan untuk guru dapat memahami karakter peserta didik dengan lebih baik. Seperti yang diketahui, proses pembelajaran adalah interaksi antara guru dan peserta didik sehingga tidak hanya guru yang harus beradaptasi. Peserta didik diharapkan dapat mengambil hikmah dari dilaksanakannya lesson study karena dalam lesson study, kegiatan peserta didik akan dipantau oleh observer. Singkatnya, proses refleksi harus dilakukan dari segi guru dan peserta didik karena proses pembelajaran adalah interaksi antara dua pelaku pembelajaran tersebut. Dengan adanya lesson study, progress yang diharapkan bisa dicatat untuk kemudian diperbaki kekurangan-kekurangan dan dipertahankan sisi positif dari pembelajaran tersebut.

\section{CONCLUSION}

Model pembelajaran problem based learning berbasis lesson study dirasa efektif dalam mengajarkan explanation text siswa SMA, dikarenakan model pembelajaran ini lebih menuntut kemampuan siswa untuk dapat bekerjasama memecahkan masalah yang diberikan guru menggunakan teks yang dipelajari. Diharapkan guru dan teman seprofesi bisa bekerja sama yang baik untuk saling memberikan masukan yang positif agar proses pembelajaran menjadi semakin baik kedepannya.

\section{REFERENCES}

Dewi, N. L. E. S., Dharsana, K., \& Renda, T. (2018). Pengaruh model pembelajaran TSTS melalui lesson study terhadap hasil belajar IPA. Jurnal Ilmiah Sekolah Dasar, 2(2), 193. https://doi.org/10.23887/jisd.v2i2.15492.

Fitriah, U., Winarti, W., \& Sukawati, S. (2019). Implementasi Metode Problem Based Learning Berbasis Audiovisual dalam Pembelajaran Menulis Teks Eksplanasi. Parole (Jurnal Pendidikan Bahasa dan Sastra Indonesia), 39(1), 39-46. http://dx.doi.org/10.22460/p.v2i1p\%25p.2056. 
Harta, J., Dharsana, I. K., \& Renda, N. T. (2019). Pengaruh Model TSTS Melalui Lesson Study Terhadap Hasil Belajar IPA. Mimbar Ilmu, 24(1), 95. https://doi.org/10.23887/mi.v24i1.17458.

Hizati, A., Ramadhan, syahrul, \& Arief, E. (2018). Pengaruh Model Problem Based Learning Berbantuan Media Gambar Berseri Terhadap Keterampilan Menulis Teks Eksplanasi Siswa Kelas Viii Smp Negeri 12 Padang. Pendidikan Bahasa Dan Sastra Indonesia, 7(1), 183-190. https://doi.org/10.31227/osf.io/mh6e3.

Karlina, C. F., Darsana, I. K., \& Kusmariyatni, N. (2017). Pembelajaran Kooperatif Tipe (TSTS) Berbantuan Peta Pikiran Untuk Meningkatkan Hasil Belajar IPA Melalui Lesson Study. Mimbar PGSD Undiksha, 5(2). http://dx.doi.org/10.23887/jjpgsd.v5i2.10883.

Kurniasih, K., Rahmati, N. A., Umamah, A., \& Widowati, D. R. (2019). English Conversation Class (ECC) untuk Menciptakan English Environment di SMA Islam Nusantara (SMAINUS). JIPEMAS: Jurnal Inovasi Hasil Pengabdian Masyarakat, 2(2), 161. https://doi.org/10.33474/jipemas.v2i2.2571.

Marhaeni, A. A. I. N. (2012). Pelatihan Pengembangan Penilaian Kinerja Menulis Bahasa Inggris Bagi Guru Bahasa Inggris SMA Kecamatan Buleleng. Jurnal Widya Laksana, 1(2). http://dx.doi.org/10.23887/jwl.v1i2.9275.

Muslainy, M. (2017). Upaya Meningkatkan Kemampuan Menulis Developing Paragraph of Explanation Text Melalui Pendekatan Contextual Teaching and Learning (CTL) pada Mata Pelajaran Bahasa Inggris Siswa Kelas XII IPA 4 SMAN 9 Pekanbaru. Jurnal PAJAR (Pendidikan dan Pengajaran), 1(1). http://dx.doi.org/10.33578/pjr.v1i1.4369.

Pangaribuan, F. R. (2020). Forts to Improve The Ability to Identify the Structure and Linguistic Elements of the Explanation Text Using the Problem Based Learning (PBL) Model for VIII Class Students. IJEMS: Indonesian Journal of Education and Mathematical Science, 1(2), 68-72. http://dx.doi.org/10.30596\%2Fijems.v1i2.5470.

Pranata, I. K. A. K. (2013). Penggunaan Teknik 3-P untuk Meningkatkan Kemampuan Menulis Berita Berbasis 5W+1H Siswa Kelas VIII A SMP Negeri 7 Singaraja. Jurnal Pendidikan Bahasa dan Sastra Undiksha, 1(1). http://dx.doi.org/10.23887/jjpbs.v1i1.282.

Ratnayanti, N. M. D., Jampel, I. N., \& Sudana, D. N. (2016). Penerapan Metode Journalist Question $(5 \mathrm{~W} 1 \mathrm{H})$ Berbantuan Media Foto Pribadi untuk Meningkatkan Keterampilan Menulis Narasi Kelas III. Mimbar PGSD Undiksha, 4(1). http://dx.doi.org/10.23887/jjpgsd.v4i1.7004.

Rohman, A. (2018). Penggunaan Model Pembelajaran Problem Based Learning untuk Meningkatkan Hasil Belajar Bahasa Inggris Pada Pokok Bahasan Explanation Text. Suara Guru: Jurnal Pendidikan Sosial, Sains, dan Humaniora, 4(2). http://dx.doi.org/10.24014/suara\%20guru.v4i2.10122.

Sahraini, S., \& Madya, S. (2015). Model Evaluasi Internal Kompetensi Guru Bahasa Inggris (Model_EIKGBI) SMA. Jurnal Penelitian dan Evaluasi Pendidikan, 19(2), 156-167. https://doi.org/10.21831/pep.v19i2.5576.

Simbolon, N. (2014). Pengaruh Pendekatan Pembelajaran Dan Kemampuan Verbal Terhadap Kemampuan Berbicara Bahasa Inggris Siswa Sma Negeri 14 Dan 21 Medan. Jurnal Cakrawala Pendidikan, 2(2), 225-235. https://doi.org/10.21831/cp.v2i2.2149.

Susanto, J. (2016). Pengembangan Perangkat Pembelajaran Berbasis Lesson Study Dengan Kooperatif Tipe Numbered Heads Together untuk Meningkatkan Aktivitas dan Hasil Belajar IPA di SD. Journal of Primary Educational, 1(7). http://dx.doi.org/10.17977/jp.v1i7.6589.

Susilo, H. (2016). Pengaruh Motivasi Belajar Siswa Dan Media Mata Pelajaran Bahasa Inggris. Jurnal Penelitian dan Pendidikan IPS (JPPI), 10(2), 218-232. 
https://ejournal.unikama.ac.id/index.php/JPPI/article/view/1717.

Widiasari, N. K. R., \& Sumantri, M. (2020). Kooperatif Tipe Group Investigation Melalui Setting Lesson Study Terhadap Kompetensi Pengetahuan IPA. Jurnal Ilmiah Sekolah Dasar, 4(2), 143. https://doi.org/10.23887/jisd.v4i2.25094.

Yulianto, A., Fatchan, A., \& Astina, I. K. (2017). Penerapan Model Pembelajaran Project Based Learning Berbasis Lesson Study untuk Meningkatkan Keaktifan Belajar Siswa. Jurnal Pendidikan, 2(3), 448-453. http://dx.doi.org/10.17977/jptpp.v2i3.8729. 